\title{
Metformin ameliorates body mass gain and early metabolic changes in ovariectomized rats
}

\author{
Clarissa Souza Barthem ${ }^{1}$, Camila Lüdke Rossetti ${ }^{1}{ }^{2}$, Denise P Carvalho ${ }^{2}$ and Wagner Seixas da-Silva ${ }^{1}$ \\ 'Laboratório de Adaptações Metabólicas, Programa de Bioquímica e Biofísica Celular, Instituto de Bioquímica Médica Leopoldo de Meis, Universidade \\ Federal do Rio de Janeiro, Rio de Janeiro, Brazil \\ ¿2Laboratório de Fisiologia Endócrina Doris Rosenthal, Instituto de Biofísica Carlos Chagas Filho, Universidade Federal do Rio de Janeiro, Rio de \\ Janeiro, Brazil
}

Correspondence should be addressed to D P Carvalho or W S da-Silva: dencarv@biof.ufrj.br or wseixas@bioqmed.ufrj.br

\begin{abstract}
Estradiol has been used to prevent metabolic diseases, bone loss and menopausal symptoms, even though it might raise the risk of cancer. Metformin is usually prescribed for type 2 diabetes mellitus and lowers food intake and body mass while improving insulin resistance and the lipid profile. Ovariectomized rats show increased body mass, insulin resistance and changes in the lipid profile. Thus, the aim of this work was to evaluate whether metformin could prevent the early metabolic dysfunction that occurs early after ovariectomy. Female Wistar rats were divided into the following groups: SHAM-operated (SHAM), ovariectomized (OVX), ovariectomized + estradiol (OVX + E2) and ovariectomized + metformin $(\mathrm{OVX}+\mathrm{M})$. Treatment with metformin diminished approximately $50 \%$ of the mass gain observed in ovariectomized animals and reduced both the serum and hepatic triglyceride levels. The hepatic levels of phosphorylated AMPactivated protein kinase (PAMPK) decreased after OVX, and the expression of the inactive form of hepatic acetyl-CoA carboxylase (ACC) was also reduced. Metformin was able to increase the levels of PAMPK in the liver of OVX animals, sustaining the balance between the inactive and total forms of ACC. Estradiol effects were similar to those of metformin but with different proportions. Our results suggest that metformin ameliorates the early alterations of metabolic parameters and rescues hepatic AMPK phosphorylation and ACC inactivation observed in ovariectomized rats.
\end{abstract}

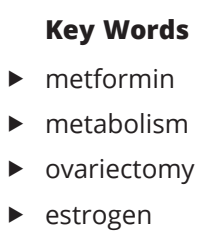

Endocrine Connections (2019) 8, 1568-1578

\section{Introduction}

Metabolic syndrome is defined as the presence of at least three of a set of features, such as abdominal obesity, high fasting glycemia, high blood pressure and dyslipidemia, which is characterized by one or more disorders as increased levels of serum triglycerides or reduced levels of high-density lipoprotein (HDL). Postmenopausal women have an elevated risk of developing metabolic syndrome compared to premenopausal women (1). In menopause, there is a reduction of ovarian function that is linked to decreased estradiol production. In this context, estrogens are used for hormone therapy to prevent the development of metabolic disorders $(2,3)$. It has been shown that although estrogen hormone replacement therapy has many benefits, it also increases the risk of developing cancer $(3,4,5)$. In this study, we used ovariectomized animals, a model in which animals have both ovaries removed and therefore mimics the estrogen deficiency that occurs during menopause. Ovariectomy is frequently used in literature for a better understanding of metabolic disorders of menopause $(6,7)$, and for testing pharmacological alternatives to prevent menopause disturbances $(8,9)$.

During recent decades, the biguanide metformin has become one of the most prescribed antidiabetic

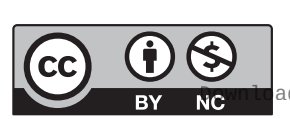


drugs worldwide. Although the mechanism of action of metformin is not fully understood (10), metformin is widely used for the treatment of metabolic disorders found in type 2 diabetes mellitus, polycystic ovary syndrome and metabolic syndrome (11). Metformin ameliorates glycemia levels, insulin sensitivity and body mass gain, which are some of the alterations detected in ovariectomized rodents $(11,12,13)$.

The goal of this study was to evaluate the effects of metformin administration in the metabolism of short-term ovariectomized rats, comparing to estrogen replacement. Metformin was able to partially prevent body mass gain and food efficiency, and the drug also prevented the increase in food ingestion. Metformin treatment also decreased hepatic and serum triglyceride levels, probably due to an increase of liver phosphorylated AMP-activated protein kinase (pAMPK) and inactivated acetyl-CoA carboxylase (ACC) levels. Taken together, our data suggest that metformin has metabolic effects similar to those observed with estradiol treatment and therefore has a potential role in the prevention of early alterations in metabolic parameters in ovariectomized rats.

\section{Materials and methods}

\section{Animals}

Female Wistar rats (Rattus norvegicus) were maintained in a 12-h light-dark cycle at a constant temperature of $22 \pm 1^{\circ} \mathrm{C}$. Water and food (NUVILAB-CR-1, from Quimtia, Parana, Brazil) were available ad libitum. Animal handling and euthanasia procedures were approved by the Institutional Animal Care and Use Committee (CEUA) of the Universidade Federal do Rio de Janeiro, Brazil (number 170/13).

\section{Animal procedure}

Female rats weighing between 180 and $220 \mathrm{~g}$ underwent ovariectomy surgery. The bilateral ovariectomy was performed by surgical procedure, as previously described with few modifications $(14,15)$. In brief, just prior the surgery, animals were weighted to calculate the amount of anesthetic required for general anesthesia. A combination of $50 \mathrm{mg} / \mathrm{kg}$ ketamine and $5 \mathrm{mg} / \mathrm{kg}$ xylazine was administrated by intraperitoneal injection. Abdominal area was cleaned with ethanol. To access peritoneal cavity, a surgical scalpel was used to make a small transverse peritoneal incision on the middle part of the lateral abdomen at both sides of the female rats.
Ovaries were identified and removed (OVX) or exposed and reinserted into the peritoneal cavity (SHAM). After the procedure, animals were divided into four groups: sham-operated rats treated with corn oil subcutaneously (vehicle) (SHAM); ovariectomized rats treated with vehicle subcutaneously (OVX); ovariectomized rats treated with $7 \mu \mathrm{g} / \mathrm{kg}$ of body mass of estradiol benzoate (SigmaAldrich) subcutaneously with an injected volume of approximately 180-250 $\mu \mathrm{L}(\mathrm{OVX}+\mathrm{E} 2)$, and ovariectomized rats treated with vehicle subcutaneously and $5 \mathrm{~g} / \mathrm{L}$ of 1,1-dimethylbiguanide hydrochloride (metformin) in drinking water (purified from Sigma-Aldrich or from commercial MERCK, Darmstadt, Germany; drugs used after filtration and validation that the biological actions were the same) $(\mathrm{OVX}+\mathrm{M})$. The dose of estradiol benzoate was the same as used by Pantaleão et al. (16). Based on Johns Hopkins manual of animal care and use committee (http://web.jhu.edu/animalcare/procedures/rat.html; retrieved August 28, 2019) and the results described by Castro et al. (17), Wistar rats drink approximately $10 \mathrm{~mL} / 100 \mathrm{~g}$ of body mass per day. This allows us to calculate a daily ingestion of approximately $500 \mathrm{mg}$ metformin/ $\mathrm{kg} / \mathrm{day}$, which is a dose used found in the literature that is able to ameliorate some cardiovascular parameters, protect against mitochondria damage, decrease insulin levels, food intake, body weight gain, serum triglycerides, increase glucose tolerance and insulin sensitivity (18, $19,20,21,22,23)$. Animals were housed individually, and daily food intake was monitored. Rats were weighed daily, and the percentage of mass gain was calculated by setting the mass immediately after surgery as 100\%. Food efficiency was calculated by the difference between final (at 20 days postsurgery) and initial (immediately after surgery) body mass, and dividing by the total food intake in grams during the 20 days of treatment of each animal.

Twenty days after ovariectomy, the rats were fasted for $14 \mathrm{~h}$ and killed by decapitation at 21 days post surgery. Blood was collected from the trunk, centrifuged at $1500 \boldsymbol{g}$ for $20 \mathrm{~min}$ at room temperature, and the serum was stored at $-80^{\circ} \mathrm{C}$. The liver, white gastrocnemius (W. Gastrocnemius) and soleus muscles, uterus,interscapular brown adipose tissue (BAT) and white adipose tissue depots (retroperitoneal, inguinal and gonadal) were excised, weighed and normalized to the rat tibia length.

\section{Serum analyses}

The levels of serum total cholesterol, total triglycerides and high-density lipoprotein (HDL) were analyzed with commercial kits (K083-2, K117-2 and K071-1, respectively

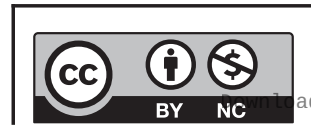


from Bioclin, Belo Horizonte, Brazil). Insulin and $17 \beta$-estradiol levels were measured by radioimmunoassay kits from MP Biomedicals (Santa Ana, USA). The quantitative insulin sensitivity check index (QUICKI) was calculated as previously described: QUICKI $=1 /$ (LOG fasting glycemia $(\mathrm{mg} / \mathrm{dL})+$ LOG fasting insulin $(\mu \mathrm{U} / \mathrm{mL}))(24)$.

\section{Hepatic cholesterol and triglyceride levels}

Protocol based on Bucolo \& David and Allain et al. (25, 26) with minor modifications, as described by Nigro et al. (27). Briefly, $30 \mathrm{mg}$ of liver was homogenized in $350 \mu \mathrm{L}$ of PBS and $350 \mu \mathrm{L}$ of $0.25 \%$ deoxycholic acid, and 10 $\mu \mathrm{L}$ of the homogenate was incubated for $5 \mathrm{~min}$ at $37^{\circ} \mathrm{C}$. Two hundred microliters of cholesterol or triglyceride (TG) reagent from a Bioclin (Belo Horizonte, Brazil) kit was added and incubated for more than $10 \mathrm{~min}$ at $37^{\circ} \mathrm{C}$. The absorbance was read at $500 \mathrm{~nm}$ according to the manufacturer's instructions.

\section{RNA isolation and quantification}

Approximately $50 \mathrm{mg}$ of liver or $100 \mathrm{mg}$ of hypothalamus was homogenized in TRI Reagent (Sigma-Aldrich) according to the manufacturer's instructions. Samples were treated with $0.04 \mathrm{IU} / \mu \mathrm{L}$ of DNase (Thermo Fisher Scientific) for $20 \mathrm{~min}$ at room temperature. After TRI Reagent extraction, cDNA was synthesized with minor alterations using $1 \mu \mathrm{L}$ of oligo dT primers and the High-Capacity cDNA Reverse
Transcription Kit (Applied Biosystems). For real-time PCR, the manufacturer's protocol from a Power SYBR Green Master Mix (Thermo Fisher Scientific) was used. The primers used are described in Table 1. mRNA expression of the genes of interest was calculated using the relative standard curve method and normalized to the mRNA expression of the housekeeping gene peptidylprolyl isomerase A, Ppia.

\section{Western blotting analysis}

Approximately $50 \mathrm{mg}$ of liver was homogenized in $500 \mu \mathrm{L}$ of buffer containing $20 \mathrm{mM}$ Tris ( $\mathrm{pH} 8.0$ ), $150 \mathrm{mM} \mathrm{NaCl}$, $2.7 \mathrm{mM} \mathrm{KCl}, 1 \mathrm{mM} \mathrm{MgCl}, 10 \%$ (v/v) glycerol, 1\% (v/v) Triton $\mathrm{X}-100,0.5 \mathrm{mMNa}_{3} \mathrm{VO}_{4}, 1 \mu \mathrm{M}$ phenylmethylsulfonyl fluoride, $10 \mathrm{mM} \mathrm{NaF}$ and $1 \times$ protease and phosphatase inhibitor cocktails (Sigma-Aldrich P8340 and P0044, respectively). After $10 \mathrm{~min}$ of centrifugation at $1500 \boldsymbol{g}$ at $4^{\circ} \mathrm{C}$, the supernatant was collected. The protein concentration was determined as described by Smith and collaborators (28) using a bicinchoninic acid assay kit (Thermo Fisher Scientific). Electrophoresis was performed on polyacrylamide SDS-PAGE gels as described by Laemmli (29) using a 7.5\% (w/v) gel for ACC and a 10\% (w/v) gel for AMPK. Wet transfer to a PVDF membrane was performed for $120 \mathrm{~min}$ at $110 \mathrm{~V}$ in a buffer containing $192 \mathrm{mM}$ glycine, $25 \mathrm{mM}$ Tris and $20 \%$ (v/v) methanol. The membranes were blocked for $1 \mathrm{~h}$ in $3 \%(\mathrm{w} / \mathrm{v})$ BSA in Tris-buffered saline containing 0.1\% (v/v) Tween 20 (TBS-T). Membranes were incubated overnight

Table 1 Primers sequence for amplification of genes in liver or hypothalamus of Wistar rats via qRT-PCR.

\begin{tabular}{|c|c|c|c|}
\hline & Sequence & NCBI reference & Fragment size (bp) \\
\hline \multirow[t]{2}{*}{ Prkaa1 } & F: CAGTACACCGTCTGATATTTTCATG & NM_019142.2 & 142 \\
\hline & R: ACAATAGTCCACACCAGAAAGG & & \\
\hline \multirow[t]{2}{*}{ Prkaa2 } & F: ACCGTTCTATTGCCACTCTG & NM_023991.1 & 126 \\
\hline & R: CTTCAGGAAAGAGGTAACTGGG & & \\
\hline \multirow[t]{2}{*}{ Acaca } & F: TCCGGCTTGCACCTAGTAAA & NM_022193.1 & 104 \\
\hline & R: CCCCCAAAACGAGTAACAA & & \\
\hline \multirow[t]{2}{*}{ Ppia } & F: GCTGTCTTTGGAACTTTGTCTG & NM_017101.1 & 129 \\
\hline & R: CCGCTGTCTCTTTTCGCC & & \\
\hline \multirow[t]{2}{*}{ Pomc } & F: CCACTGAACATCTTCGTCCTC & NM_139326.2 & 75 \\
\hline & R: GAATCTCGGCATCTTCCAGG & & \\
\hline \multirow[t]{2}{*}{ Npy } & F: GACAGAGATATGGCAAGAGATCC & NM_012614.2 & 148 \\
\hline & R: CTAGGAAAAGTCAGGAGAGCAAG & & \\
\hline \multirow[t]{2}{*}{ Agrp } & F: CCATATAAGCTCAGGGCACAAG & NM_033650.1 & 93 \\
\hline & R: GACACAGCTCAGCAACATTG & & \\
\hline \multirow[t]{2}{*}{ Pmch } & F: ATTCTCCСCACATTCTCTTCG & NM_012625.1 & 143 \\
\hline & R: CTACGTTCCTGATGGACTTGG & & \\
\hline \multirow[t]{2}{*}{$A c t b$} & F: ACAACCTTCTTGCAGCTCCTC & NM_031144.3 & 275 \\
\hline & R: GCCGTGTTCAATGGGGTACT & & \\
\hline
\end{tabular}

Acaca, acetyl-CoA carboxylase alpha; Actb, actin, beta; Agrp, Agouti-related neuropeptide; Npy, Neuropeptide Y; Pmch, pro-melanin-concentrating hormone; Pomc, proopiomelanocortin; Ppia, peptidylprolyl isomerase A; Prkaa1 and Prkaa2, protein kinase AMP-activated catalytic subunit alpha 1 or 2, respectively; Srebf1, sterol regulatory element-binding transcription factor 1.

https://ec.bioscientifica.com https://doi.org/10.1530/EC-19-0470 (c) 2019 The authors Published by Bioscientifica Ltd

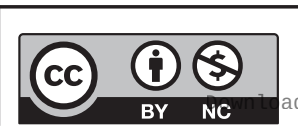

This work is licensed under a Creative Commons Attribution-NonCommercial 4.0 International License. ded from Bioscientifica.com at 04/26/2023 01:00:28PM 
Table 2 Antibodies.

\begin{tabular}{|c|c|c|}
\hline & Reference & Dilution \\
\hline Phospho-AMPK $\alpha$ (Thr172) & \#2531 (Cell Signaling) & $1: 2500$ \\
\hline $\mathrm{AMPK} \alpha$ & \#2532 (Cell Signaling) & $1: 2000$ \\
\hline $\begin{array}{l}\text { Phospho-acetyl-CoA } \\
\text { carboxylase (Ser79) }\end{array}$ & \#3661 (Cell Signaling) & $1: 2500$ \\
\hline Acetyl-CoA carboxylase & \#3662 (Cell Signaling) & $1: 2500$ \\
\hline Monoclonal anti- $\alpha$-tubulin & T5168 (Sigma) & $1: 25,000$ \\
\hline Anti-rabbit IgG & A0545 (Sigma) & $1: 2500$ \\
\hline Anti-mouse IgG & A3673 (Sigma) & $1: 2500$ \\
\hline
\end{tabular}

with the appropriate primary antibodies (Table 2). Then, the membranes were washed and incubated with the appropriate secondary antibody for $1 \mathrm{~h}$. After detection of the immunocomplex using a Luminata Forte Western HRP Substrate (Millipore), the membranes were incubated with $0.01 \%(\mathrm{w} / \mathrm{v})$ sodium azide in $3 \%(\mathrm{v} / \mathrm{v})$ BSA in TBS-T to inhibit the signal from the secondary antibody. Then, immunodetection was also performed for $\alpha$-tubulin as a loading control. Images were quantified using ImageJ $1.52 \mathrm{a}$ software (National Institutes of Health, NIH, Bethesda, USA) (30). Western blotting for phosphorylated and total ACC, and phosphorylated and total AMPK proteins, were done using different polyacrylamide gels and thus values of the same animal were normalized.

\section{Statistical analysis}

Data are expressed as the mean \pm S.E.M. and were analyzed using GraphPad Prism 6 Software. Daily body mass gain was analyzed by two-way ANOVA followed by Bonferroni's post-test. All the other data were analyzed by one-way ANOVA with Tukey's post-test to detect the differences between all groups. Statistical significance was inferred when $P<0.05$. Symbols were used to describe $P$ values smaller than 0.05 .

\section{Results}

\section{Effects of estradiol and metformin on the body mass gain and food intake of ovariectomized rats}

Based on the various well-described benefits of metformin, we decided to investigate the effect of this drug on the phenotype observed in ovariectomized rats. As documented previously (27), sham-operated (SHAM) rats showed a progressive elevation of their body masses from day 1 to the end of day 20 after surgery (data not shown).

In agreement with the literature $(6,9,13)$, the ovariectomized animals gained significantly more body

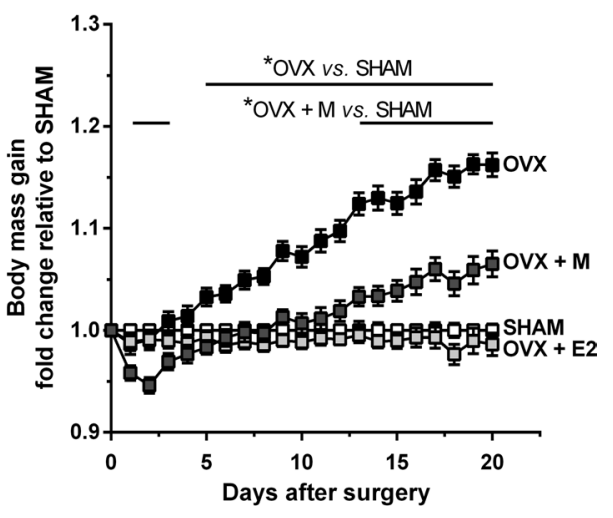

Figure 1

Body mass gain in ovariectomized Wistar rats treated with estradiol or metformin. Body mass was measured during the 20 days postsurgery. The body mass percentage was calculated based on the body mass just after surgery and normalized to the SHAM mean of each experimental procedure for each day after surgery. The animal groups were SHAMoperated rats treated with vehicle (SHAM), ovariectomized rats treated with vehicle $(\mathrm{OVX})$, ovariectomized rats treated with $7 \mu \mathrm{g} / \mathrm{kg}$ of body mass of estradiol benzoate $(O V X+E 2)$ and ovariectomized rats treated with vehicle and $5 \mathrm{~g} / \mathrm{L}$ of metformin in the drinking water $(\mathrm{OVX}+\mathrm{M})$. Data are shown as the mean \pm S.E.M. of 13-18 animals per experimental group. Two-way ANOVA was used to compare groups and followed by Bonferroni's post-test to detect differences compared with the SHAM group. ${ }^{*} P<0.05$.

mass than the SHAM animals (Fig. 1, black and white squares, respectively). Estradiol replacement completely prevented body mass gain in the OVX animals (OVX $+\mathrm{E} 2$, light gray squares), and metformin administration $(5 \mathrm{~g} / \mathrm{L}$ in drinking water) was also able to attenuate body mass gain in the OVX group (OVX $+\mathrm{M}$, dark gray squares); while the OVX rats presented a $16 \%$ body mass gain, the OVX $+\mathrm{M}$ group gained only $7 \%$ more body mass than SHAM group (Table 3). The prevention of body mass gain was statistically significant from the $13^{\text {th }}$ day after surgery onward, although the trend was already observed in the first days of metformin administration.

To further understand the change in body mass, we weighed several tissues (Table 3). We did not observe any changes in the W. Gastrocnemius portion, soleus or BAT mass. Twenty-one days after OVX, an increased inguinal white adipose tissue content was observed in OVX rats compared to SHAM group $(P=0.09)$. This effect was prevented by estradiol treatment, and metformin promotes a decrease $(P=0.11)$ comparing to OVX. There was a trend to increase retroperitoneal adipose tissue mass in OVX rats $(P=0.12)$ that was abolished in the metformin and estradiol treatment groups comparing to SHAM. We also observed an increase in the liver mass of OVX $+\mathrm{E} 2$ rats, although their liver triglyceride content was reduced (Fig. 3). This increment might be an effect of estradiol increasing cell proliferation, as already documented (31).
This work is licensed under a Creative Commons Attribution-NonCommercial 4.0 International License. ded from Bioscientifica.com at 04/26/2023 01:00:28PM via free access 
Table 3 Body mass gain and tissue mass/tibia length at the end of the 21 days of treatment.

\begin{tabular}{lc}
\hline & SHAM \\
\cline { 1 - 1 } Body mass gain & $1.00 \pm 0.01$ \\
Uterus & $1.00 \pm 0.08$ \\
Liver & $1.00 \pm 0.02$ \\
BAT & $1.00 \pm 0.05$ \\
Retroperitoneal & $1.00 \pm 0.06$ \\
Inguinal & $1.00 \pm 0.04$ \\
Gonadal & $1.00 \pm 0.06$ \\
W. Gastrocnemius & $1.00 \pm 0.05$ \\
Solear & $1.00 \pm 0.03$ \\
\hline
\end{tabular}

\begin{tabular}{c}
\hline ovx \\
\hline $1.16 \pm 0.01^{\mathrm{b}}$ \\
$0.24 \pm 0.01^{\mathrm{b}}$ \\
$1.05 \pm 0.02$ \\
$1.07 \pm 0.07$ \\
$1.35 \pm 0.18$ \\
$1.17 \pm 0.05$ \\
$1.02 \pm 0.01$ \\
$1.05 \pm 0.04$ \\
$1.02 \pm 0.02$ \\
\hline
\end{tabular}

\begin{tabular}{l}
\hline OVX +E2 \\
\hline $0.99 \pm 0.01^{d}$ \\
$1.25 \pm 0.09^{d, a}$ \\
$1.13 \pm 0.03^{b}$ \\
$1.12 \pm 0.06$ \\
$0.97 \pm 0.04$ \\
$0.97 \pm 0.05^{c}$ \\
$0.94 \pm 0.07$ \\
$0.99 \pm 0.03$ \\
$1.00 \pm 0.03$ \\
\hline
\end{tabular}

\begin{tabular}{c}
\hline $\mathbf{O V X}+\mathbf{M}$ \\
\hline $1.07 \pm 0.01^{\mathrm{d}, \mathrm{b}, \mathrm{f}}$ \\
$0.25 \pm 0.02^{\mathrm{b}, \mathrm{f}}$ \\
$1.02 \pm 0.03^{\mathrm{e}}$ \\
$1.16 \pm 0.05$ \\
$1.13 \pm 0.09$ \\
$1.01 \pm 0.06$ \\
$0.88 \pm 0.06$ \\
$0.99 \pm 0.05$ \\
$1.02 \pm 0.07$
\end{tabular}

White adipose tissue depots (retroperitoneal, inguinal and gonadal); BAT, interscapular brown adipose tissue; W. gastrocnemius, gastrocnemius-white portion. Values of SHAM means: body mass weight at 20 days post surgery: $211.9 \pm 3.4$ g; uterus: $16.5 \pm 1.8 \mathrm{mg} / \mathrm{mm}$; liver: $180.9 \pm 3.9 \mathrm{mg} / \mathrm{mm}$; BAT: $5.9 \pm 0.5 \mathrm{mg} / \mathrm{mm}$; retroperitoneal: $33.5 \pm 4.4 \mathrm{mg} / \mathrm{mm}$; inguinal: $68.8 \pm 5.8 \mathrm{mg} / \mathrm{mm}$; gonadal: $52.9 \pm 6.0 \mathrm{mg} / \mathrm{mm}$; W. Gastrocnemius: $14.5 \pm 1.8 \mathrm{mg} / \mathrm{mm}$; solear: $5.0 \pm 0.3 \mathrm{mg} / \mathrm{mm}$. Data were normalized by sham mean of each experimental procedure and represented as mean \pm S.E.M., $n=10-11$. One-way ANOVA was used to compare groups, followed by Tukey's post-test to detect differences: ${ }^{a} P<0.05,{ }^{b} P<0.01$ vs SHAM group; ${ }^{c} p<0.05$, d $P<0.01$ vs OVX group; ${ }^{e} P<0.05,{ }^{f} P<0.01$ vs OVX $+E 2$ group.

Although OVX animals showed a significant increase in food intake (Table 4), it was not solely responsible for the observed increase in body mass since food efficiency (body mass gain/food intake) was also increased in OVX rats. Metformin treatment prevented the increase in food intake but did not completely normalize food efficiency, since it was smaller in the $\mathrm{OVX}+\mathrm{M}$ than in the OVX group, but was higher in $\mathrm{OVX}+\mathrm{M}$ than in the SHAM group. Estradiol treatment completely prevented the increase in both food intake and food efficiency.

To better understand the alterations in food intake observed in OVX rats, we analyzed the hypothalamic mRNA levels of orexigenic and anorexigenic markers (Fig. 2), but the levels were unaltered.

\section{Serum hormone levels}

Despite the slight increase in insulin levels in the OVX +E2 group comparing to SHAM group $(P=0.06)$, and the significant increase comparing OVX and OVX $+\mathrm{M}$ groups, glycemia did not differ among the groups. However, metformin treatment slightly increased QUICKI index when comparing to OVX +E2 (Table 4). Although minor changes were detected in OVX $+\mathrm{E} 2$ group, we observed that short-term ovariectomy did not significantly alter these parameters.

Although serum 17 $\beta$-estradiol levels were not significantly decreased in the OVX and OVX $+\mathrm{M}$ groups, these groups showed a significant decrease in uterus mass (Tables 3 and 4), which indicates atrophy of this tissue. The OVX $+\mathrm{E} 2$ group showed increase in both $17 \beta$-estradiol serum levels and uterus mass.

\section{Serum and hepatic lipid profiles}

The OVX group showed a statistically significant increase in serum cholesterol levels, with no statistical changes in the OVX+E2 and OVX $+\mathrm{M}$ groups (Fig. 3A). Despite this observation, there was a decrease in the hepatic cholesterol levels in OVX $+\mathrm{E} 2$ in comparation to OVX and OVX $+\mathrm{M}$ groups (Fig. 2B).

Table 4 Animal parameters.

\begin{tabular}{|c|c|c|}
\hline & SHAM & ovx \\
\hline Food intake & $1.00 \pm 0.02$ & $1.16 \pm 0.03^{a}$ \\
\hline Food efficiency & $1.00 \pm 0.14$ & $3.33 \pm 0.31^{a}$ \\
\hline Glycemia & $1.00 \pm 0.02$ & $1.02 \pm 0.04$ \\
\hline Insulin & $1.00 \pm 0.04$ & $0.97 \pm 0.04$ \\
\hline QUICKI & $1.00 \pm 0.01$ & $1.00 \pm 0.01$ \\
\hline $17 \beta$-estradiol & $1.00 \pm 0.10$ & $0.71 \pm 0.06$ \\
\hline
\end{tabular}

\begin{tabular}{l}
\hline $\mathbf{O V X}+\mathbf{E 2}$ \\
\hline $1.02 \pm 0.28^{\mathrm{c}}$ \\
$0.59 \pm 0.20^{\mathrm{c}}$ \\
$1.01 \pm 0.03$ \\
$1.20 \pm 0.07^{\mathrm{b}}$ \\
$0.97 \pm 0.01$ \\
$3.24 \pm 0.22^{\mathrm{c}, \mathrm{a}}$ \\
\hline
\end{tabular}

\begin{tabular}{l}
\hline \multicolumn{1}{c}{$\mathbf{\text { VVX } + \mathbf { M }}$} \\
\hline $0.98 \pm 0.02^{\mathrm{c}}$ \\
$2.02 \pm 0.19^{\mathrm{c}, \mathrm{a}, \mathrm{e}}$ \\
$0.94 \pm 0.03$ \\
$0.96 \pm 0.05^{\mathrm{d}}$ \\
$1.01 \pm 0.01^{\mathrm{d}}$ \\
$0.93 \pm 0.11^{\mathrm{e}}$
\end{tabular}

Values of SHAM means: food intake: $378 \pm 15 \mathrm{~g}$; food efficiency: $0.042 \pm 0.005$ g/g; glycemia: $94.4 \pm 3.2 \mathrm{mg} / \mathrm{dL}$; insulin: $14.4 \pm 0.8 \mu$ lU/mL; QUICKI: $0.321 \pm 0.004 ; 17 \beta$-estradiol: $117.0 \pm 20.89 \mathrm{pg} / \mathrm{mL}$. Data were normalized by SHAM mean of each experimental procedure and represented as mean \pm S.E.M., $n=9-18$. One-way ANOVA was used to compare groups, followed by Tukey's post-test to detect differences: a $P<0.01$ vs SHAM group; ${ }^{\mathrm{b}} P<0.05,{ }^{\mathrm{c}} P<0.01$ vs OVX group; ${ }^{\mathrm{d}} P<0.05,{ }^{\mathrm{e}} p<0.01$ vs OVX + E2 group.

https://ec.bioscientifica.com https://doi.org/10.1530/EC-19-0470 (c) 2019 The authors Published by Bioscientifica Ltd

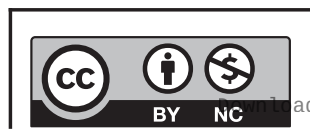

This work is licensed under a Creative Commons Attribution-NonCommercial 4.0 International License. ded from Bioscientifica.com at 04/26/2023 01:00:28PM 
A
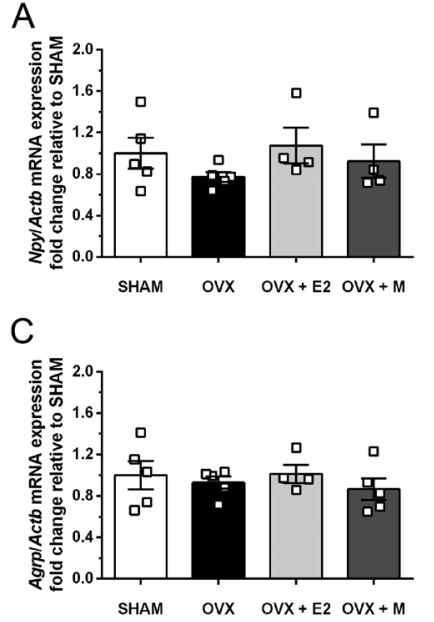

B

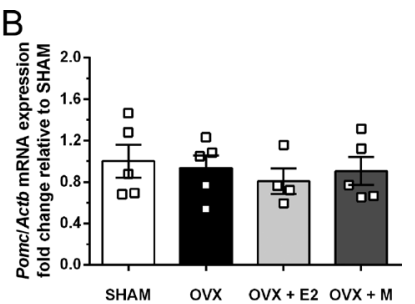

D

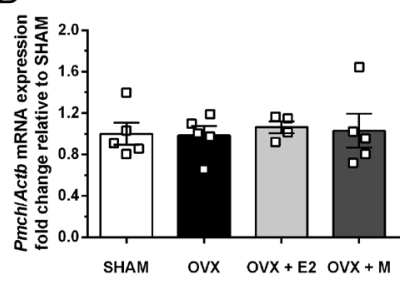

Figure 2

Hypothalamus mRNA expression. qRT-PCR for (A) Npy, neuropeptide $Y$, (B) Pomc, proopiomelanocortin, (C) Agrp, Agouti-related neuropeptide, (D) Pmch, pro-melanin-concentrating hormone expression. The quantity of each target gene was normalized to that of Actb, actin, beta in the respective sample $(n=4-5)$. Data were normalized to the SHAM mean of each experimental procedure and are represented as the mean \pm S.E.M. One-way ANOVA was used to compare groups and was followed by Tukey's post-test to detect the differences between groups. No statistically significant differences were detected.

Triglyceride levels were reduced in the serum of OVX rats but did not change in the liver. The OVX $+\mathrm{E} 2$ group had an opposite profile, with no changes in serum TG levels compared to SHAM and lower hepatic TG levels compared to SHAM and OVX. In contrast, metformin treatment reduced both the serum and hepatic triglyceride content comparing to SHAM and OVX group, respectively.

\section{Hepatic AMPK and ACC levels}

Since it is known that metformin is a potent activator of AMPK and to better understand the reduction in the serum and hepatic triglyceride levels observed in the OVX $+\mathrm{M}$ rats, we investigated the protein levels of AMPK and ACC in our model. AMPK plays a key role in metabolic homeostasis in the cell. Activated AMPK (pAMPK) phosphorylates ACC, leading to the inhibition of ACC and the blockade of lipid synthesis (32).

Hepatic pAMPK (Thr-172) levels were analyzed by Western blotting (Fig. 4A), and OVX diminished pAMPK levels, but this decrease was prevented by the estradiol and metformin treatments. We did not observe any changes in total AMPK (Fig. 4B). Although there were no statistical changes in pAMPK/tAMPK ratio (Fig. 4C), we observed the same expression profile as seen in pAMPK. No alterations were seen in AMPK mRNAs expression:
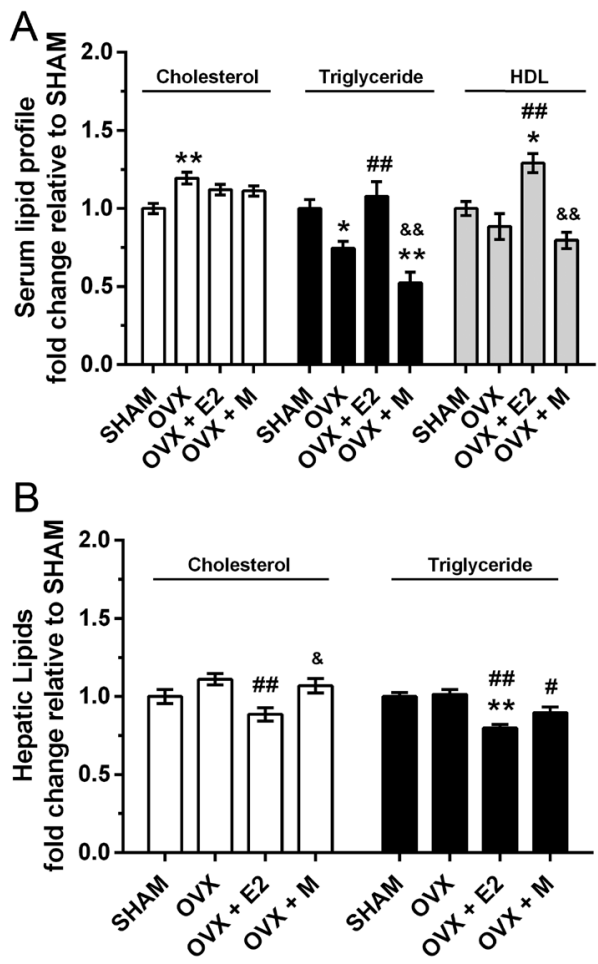

Figure 3

Lipid profile. (A) Serum lipid profile. Animals were fasted for $14 \mathrm{~h}$ before being killed by decapitation, and their blood was collected and centrifuged as described in the 'Materials and methods' section. The cholesterol (white bars; SHAM mean $65.0 \pm 2.7 \mathrm{mg} / \mathrm{dL}$ ), triglyceride (black bars, SHAM mean $30.7 \pm 2.6 \mathrm{mg} / \mathrm{dL}$ ), and HDL (gray bars, SHAM mean $20.2 \pm 1.0 \mathrm{mg} / \mathrm{dL}$ ) levels were analyzed using commercial kits $(n=7-14)$. (B) The hepatic cholesterol (white bars, SHAM mean $3.8 \pm 0.3 \mathrm{mg} / \mathrm{g}$ ) and triglyceride (black bars, SHAM mean $16.2 \pm 0.6 \mathrm{mg} / \mathrm{g}$ ) levels were analyzed using commercial kits $(n=13-18)$. Data were normalized to the SHAM mean of each experimental procedure and are represented as the mean \pm S.E.M. One-way ANOVA was used to compare groups and was followed by Tukey's post-test to detect differences: $* P<0.05, * * P<0.01$ vs SHAM group; ${ }^{\#} P<0.05,{ }^{\# \#} P<0.01$ vs OVX group; ${ }^{\&} P<0.05$, ${ }^{\&} \& P<0.01$ vs OVX $+E 2$ group.

protein kinase AMP-activated catalytic subunit alpha 1 (Prkaa1) and alpha 2 (Prkaa2) (Fig. 4D).

As expected given the reduced levels of pAMPK, pACC levels were also reduced in the OVX rats, but interestingly, metformin treatment did not normalize pACC levels (Fig. 5A). However, we noticed that the total ACC levels tended to decrease in the $\mathrm{OVX}+\mathrm{M}$ group comparing to SHAM $(P=0.06)$ (Fig. $5 \mathrm{~B})$. The data from Fig. $5 \mathrm{~A}$ and $\mathrm{B}$ allowed us to estimate the amount of ACC in the inactive state using the ratio of pACC/total ACC. As shown in Fig. 5C, we observed decreased levels of ACC inhibition only in the ovariectomized rats, thus metformin treatment increased the amount of ACC inhibition, which was not significantly different from neither SHAM nor OVX groups. Acetyl-CoA carboxylase alpha (Acaca) mRNA levels,

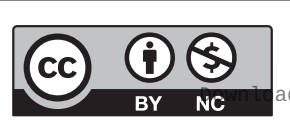



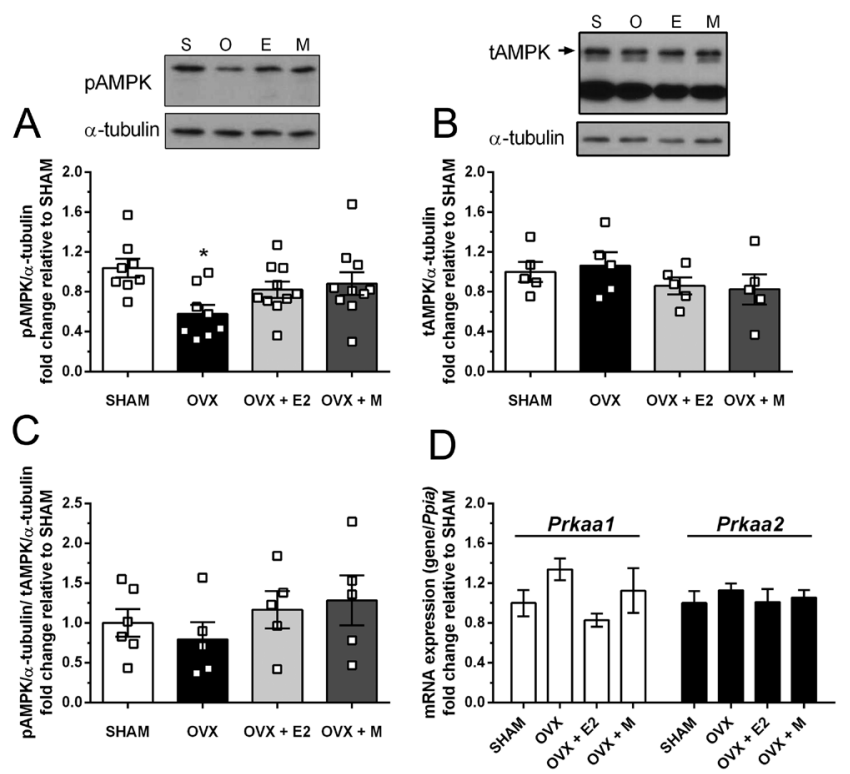

\section{Figure 4}

AMPK levels in the liver. (A) Western blotting for pAMPK $(n=8-10)$ and (B) total AMPK (tAMPK) $(n=5)$. Fifteen micrograms of total liver homogenate derived from the different experimental groups was loaded on the gel. The immunodetection was performed with an anti-pAMPK or anti-tAMPK antibody. After an overnight incubation in $0.01 \%$ sodium azide in 3\% BSA, an anti- $\alpha$-tubulin antibody was used as the loading control.

Representative experiments for PAMPK, tAMPK and $\alpha$-tubulin detection are shown. Each lane represents one animal. S, SHAM; O, OVX; E, $\mathrm{OVX}+\mathrm{E} 2 ; \mathrm{M}, \mathrm{OVX}+\mathrm{M}$. (C) The values of $\mathrm{PAMPK} / \alpha$-tubulin were normalized to those of tAMPK/ $\alpha$-tubulin in each sample $(n=4-6)$. (D) qRT-PCR for Prkaa1 expression and Prkaa2 expression. The quantity of each target gene was normalized to that of Ppia in the respective sample $(n=8-10)$. Data were normalized to the SHAM mean of each experimental procedure and are represented as the mean \pm S.E.M. One-way ANOVA was used to compare groups and was followed by Tukey's post-test to detect differences: ${ }^{*} P<0.05$ vs SHAM group.

which encodes ACC, were higher in the OVX rats treated with estradiol (Fig. 5D), corroborating the rise in the ACC protein levels. Since metformin treatment did not change the ACC mRNA levels, our results suggest that metformin acts mainly by post-transcriptional regulation of the AMPK/ACC pathway in this ovariectomized rat model.

\section{Discussion}

Here we show that, similar to estradiol administration, metformin treatment improves metabolism in ovariectomized rats, although the treatments achieved different degrees of impact. We focused in metformin prevention of ovariectomy's metabolic effects. To minimized the effects of obesity that naturally develops after ovariectomy in rats (8), we have chosen a short-term treatment of only 21 days with a normal diet.
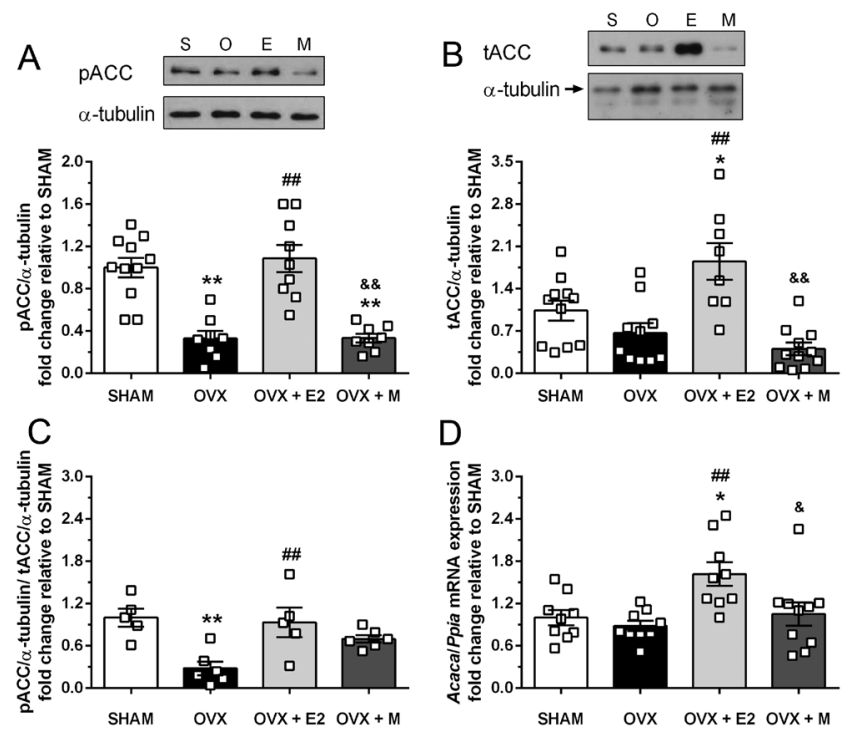

\section{Figure 5}

Hepatic ACC levels. (A) Western blotting for pACC $(n=8-11)$ and (B) total ACC (tACC) $(n=8-11)$. Fifteen micrograms of total liver homogenate derived from the different experimental groups was loaded on the gel. The immunodetection was performed with an anti-pACC or anti-tACC antibody. After an overnight incubation in $0.01 \%$ sodium azide in $3 \%$ BSA, an anti- $\alpha$-tubulin antibody was used as the loading control.

Representative experiments for pACC, tACC and $\alpha$-tubulin detection, where each lane represents one animal, are shown. S, SHAM; O, OVX; E, $\mathrm{OVX}+\mathrm{E} 2 ; \mathrm{M}, \mathrm{OVX}+\mathrm{M}$. (C) The values of $\mathrm{pACC} / \alpha$-tubulin were normalized to those of tACC/ $\alpha$-tubulin in each sample $(n=5-6)$. (D) qRT-PCR for Acaca expression. The quantity of the target gene was normalized to that of Ppia of in the sample $(n=9-10)$. Data were normalized to the SHAM mean of each experimental procedure and are represented as the mean \pm S.E.M. One-way ANOVA was used to compare groups and was followed by Tukey's post-test to detect differences: ${ }^{*} P<0.05, * \star P<0.01$ vs SHAM group; $\# P<0.01$ vs OVX group; $\& P<0.05$, \&\& $P<0.01$ vs OVX + E2 group.

Metformin is widely known to reduce body mass gain in human (33), rats (34) and mice (35), but in ovariectomized rodents, the effect of metformin on metabolism has been poorly explored. However, there are a few studies that investigated the treatment with metformin for 1 (36) or 4 weeks $(37,38)$ that confirmed our results of reduced body mass gain (Fig. 1), but these studies did not focus on metabolic pathways.

Ovariectomy is known to augment adipose tissue depots, but this is usually shown with a longer postOVX time course or the ingestion of a high-fat diet $(13,39)$. We observed a tendency to increase inguinal and retroperitoneal adipose tissue depot in this shortterm post-OVX that was prevented by metformin and estradiol treatment (Table 3). This observation alone does not explain the differences observed in body mass gain. Further studies should be performed to investigate the observed effects on body mass gain. In agreement with previous works $(27,40)$, here we found a rise in food

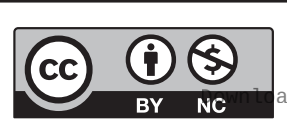

This work is licensed under a Creative Commons Attribution-NonCommercial 4.0 International License. ded from Bioscientifica.com at 04/26/2023 01:00:28PM 
efficiency induced by ovariectomy in the rats. For the first time of our knowledge, we identified that metformin treatment was able to decrease food efficiency (Table 4), showing that this drug can attenuate the development of early alterations observed in metabolic parameters detected in ovariectomized rats. In the present study, we show that metformin administration, as well as estradiol treatment, normalizes the food intake of OVX rats; however, previous studies in mice treated with a lower dose of metformin did not find similar results (37).

It has been shown that estradiol increases anorexigenic Pomc and decreases orexigenic Npy mRNA expression (41) and that metformin reduced the mRNA levels of $N p y$ in a diabetic animal model and in cultured hypothalamic neurons $(42,43)$. Here, we did not find any differences in Npy, Pomc, Agrp and Pmch expression (Fig. 3), probably due to the $14 \mathrm{~h}$ of fasting used in this study to allow the analysis of serum lipids. Perhaps, this prolonged fasting time had hyper stimulated the expression of orexigenic genes and inhibited the expression of anorexigenic gene.

Fasting glycemia did not change in this short time after ovariectomy, and insulin levels were increased only by estradiol treatment, which might be due to the positive effect of estradiol on insulin secretion (44). This led to a minor increase of insulin sensitivity, detected by QUICKI calculation by metformin treatment when to OVX $+\mathrm{E} 2$ group (Table 4).

Natural menopause in rodents occurs with the arrest of regular ovarian cycling, followed by irregular cycling, and then an arrest in cycling that maintains a constant cycle phase without a reduction in the estradiol levels (45). We did not observe any significant changes in serum $17 \beta$-estradiol levels in the OVX rats at 21 days, although some previous studies have reported decreased serum estradiol in models of ovariectomy $(7,46)$. Vaginal smears showed that the OVX and OVX $+\mathrm{M}$ rats were in a constant diestrous phase (data not shown), and uterus mass was hypotrophic in these two groups, demonstrating a low estradiol effect. The dose of $17 \beta$-estradiol administered was based on previous works and has been reported to be enough to abolish the body mass gain in ovariectomized rats $(16,27)$.

Pedram et al. (47) showed that estradiol activates AMPK, which diminishes the activation and mRNA levels of sterol regulatory element-binding transcription factor 1 (Srebf1), which encodes sterol regulatory element-binding protein-1 (SREBP1), an important transcription factor of several lipogenic genes, and also decreases 3-hydroxy-3methylglutaryl CoA reductase (Hmgcr), which encodes 3-hydroxy-3-methylglutaryl-coenzyme A (HMG-CoA) reductase, a key enzyme of cholesterol synthesis. Although the role of estradiol in preventing the increase in serum cholesterol levels has already been described in a longer treatment protocol (48), we did not observe any significant changes in the serum cholesterol levels, and only a slight decrease in hepatic cholesterol in OVX +E2 comparing to OVX group (Fig. 2) or the Srebf1 mRNA levels (fold change relative to SHAM; SHAM: $1.00 \pm 0.20$; OVX: $0.76 \pm 0.13 ; \mathrm{OVX}+\mathrm{E} 2: 0.75 \pm 0.16$; OVX $+\mathrm{M}: 0.90 \pm 0.17$ ). We did not observe any significant effects of metformin on the serum and hepatic cholesterol levels of OVX rats when comparing to SHAM or OVX groups, despite the findings of Sivasinprasasn et al. (37), who observed a reduction in the serum cholesterol levels in 12 weeks post-OVX rats treated with metformin for more 4 weeks. Although the effects of metformin on cholesterol levels have already been demonstrated in other models (49, 50 ), the action of metformin in ovariectomized rats needs to be further studied.

Estradiol has been shown to play an important role in the expression of proteins involved in the hepatic production and formation of lipoproteins. This could explain the diminished levels of serum triglycerides observed in OVX rats, although we were not able to detect alterations in the hepatic TG content, as it has been seen in longer treatment models $(9,13,51,52)$. Geerling et al. (53) showed that metformin increases the mass and activity of BAT, draining serum triglycerides. We did not observe any alteration in BAT mass (Table 3 ) and in content of triglyceride per gram of tissue (data not shown). In fact, Nigro et al. (27) have shown, using the same experimental model, no alterations in BAT activity (oxygen consumption, ATP synthesis, and heat production) in ovariectomized rats. The authors have also found no differences in UCP1 protein levels and PGC1 $\beta$ mRNA expression in this tissue. So, BAT does not seem to be a metabolic target of changes in this short-term ovariectomy in rats, but further analysis is needed to exclude if metformin acts modulating BAT metabolism in this model. We saw a decrease in the levels of both serum and hepatic triglycerides, suggesting alterations in their production, utilization and/or absorption.

The precise mechanism by which metformin activates AMPK is still unknown, but it is widely accepted that this drug indirectly stimulates AMPK activation $(10,54$, 55). We showed that the effect of metformin is preserved in the liver of OVX rats (Fig. 4). Our study suggests that metformin is able to regulate the amount of total ACC, and increases the levels of the inactive state protein observed in this work (Fig. 5C).

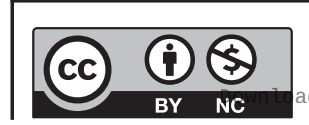


AMPK is known as a metabolic sensor and has already been shown to be responsible for increased lipolysis, fatty acid $\beta$-oxidation and mitochondrial biogenesis and to induce decreases in fatty acid synthesis and gluconeogenesis, among other effects (32). All these functions are impaired after ovariectomy $(13,27,56,57$, 58,59 ), providing evidence that AMPK may be a key protein involved in the metabolic dysfunction that occurs due to the estrogen deficiency induced by ovariectomy. ACC is a limiting enzyme for lipogenic synthesis. Fullerton et al. (60) showed in mice that a mutation in ACC that inhibits ACC phosphorylation by AMPK causes increased hepatic lipogenesis and decreased hepatic $\beta$-oxidation as well as insulin resistance and glucose intolerance. These features are also observed in ovariectomized models (13, $56,58)$. Thus, AMPK and ACC may be implicated in the benefits promoted by metformin and estradiol in ovariectomized animals.

Here, we showed that metformin, by preventing increases in body mass and serum and hepatic triglyceride levels as well as avoiding the inactivation of hepatic AMPK/ACC, is a potential drug to prevent the early metabolic impairment observed in ovariectomized rats. Further studies should be performed to investigate whether metformin treatment would have the same effect in a long-term ovariectomy model.

\section{Declaration of interest}

The authors declare that there is no conflict of interest that could be perceived as prejudicing the impartiality of the research reported.

\section{Funding}

This work was supported by Coordenação de Aperfeiçoamento de Pessoal de Nível Superior (CAPES), Conselho Nacional de Desenvolvimento Científico e Tecnológico (CNPq) and Fundação de Amparo à Pesquisa do Estado do Rio de Janeiro (FAPERJ), which is funded by the Brazilian government.

\section{Acknowledgements}

The authors thank Dr Anderson Teixeira Santos and Dr Michele Hinerasky da Silva from Universidade Federal do Rio de Janeiro for their help in the animal surgical procedure and for their help to collect animal samples.

\section{References}

1 Park YW, Zhu S, Palaniappan L, Heshka S, Carnethon MR \& Heymsfield SB. The metabolic syndrome: prevalence and associated risk factor findings in the US population from the third National Health and Nutrition Examination Survey, 1988-1994. Archives of Internal Medicine 2003163 427-436. (https://doi.org/10.1001/ archinte.163.4.427)
2 Salpeter SR, Walsh JME, Ormiston TM, Greyber E, Buckley NS \& Salpeter EE. Meta-analysis: effect of hormone-replacement therapy on components of the metabolic syndrome in postmenopausal women. Diabetes, Obesity and Metabolism 20068 538-554. (https:// doi.org/10.1111/j.1463-1326.2005.00545.x)

3 Rossouw JE, Anderson GL, Prentice RL, LaCroix AZ, Kooperberg C, Stefanick ML, Jackson RD, Beresford SAA, Howard BV, Johnson KC, et al. Risks and benefits of estrogen plus progestin in healthy postmenopausal women: principal results From the Women's Health Initiative randomized controlled trial. JAMA $2002 \mathbf{2 8 8} 321-333$. (https://doi.org/10.1001/jama.288.3.321)

4 Vazquez Rodriguez G, Abrahamsson A, Jensen LDE \& Dabrosin C. Estradiol promotes breast cancer cell migration via recruitment and activation of neutrophils. Cancer Immunology Research $2017 \mathbf{5}$ 234-247. (https://doi.org/10.1158/2326-6066.CIR-16-0150)

5 Brusselaers N, Tamimi RM, Konings P, Rosner B, Adami HO \& Lagergren J. Different menopausal hormone regimens and risk of breast cancer. Annals of Oncology 201829 1771-1776. (https://doi. org/10.1093/annonc/mdy212)

6 Curtis KS, McCracken K, Espinosa E, Ong J, Buck DJ \& Davis RL. Temporal and site-specific changes in central neuroimmune factors during rapid weight gain after ovariectomy in rats. Neurochemical Research 201843 1802-1813. (https://doi.org/10.1007/s11064-0182596-6)

7 Tang Z, Wang Y, Zhu X, Ni X, Cong B \& Lu J. Reduced expression of CRHR2 and Sp-1 in myocardium of ovariectomized rats is improved by exercise training. Gynecological Endocrinology 201531 742-746. (https://doi.org/10.3109/09513590.2015.1056729)

8 Tsai YC, Leu SY, Chen SY, Kung CW, Lee YM, Liu YP, Yen MH \& Cheng PY. 17-DMAG, an Hsp90 inhibitor, ameliorates ovariectomyinduced obesity in rats. Life Sciences 2019232 116672. (https://doi. org/10.1016/j.lfs.2019.116672)

9 Jeong YH, Hur HJ, Jeon EJ, Park SJ, Hwang JT, Lee AS, Lee KW \& Sung MJ. Honokiol improves liver steatosis in ovariectomized mice. Molecules 201823 1-8. (https://doi.org/10.3390/molecules23010194)

10 Rena G, Hardie DG \& Pearson ER. The mechanisms of action of metformin. Diabetologia 201760 1577-1585. (https://doi. org/10.1007/s00125-017-4342-z)

11 Pernicova I \& Korbonits M. Metformin - mode of action and clinical implications for diabetes and cancer. Nature Reviews: Endocrinology 201410 143-156. (https://doi.org/10.1038/nrendo.2013.256)

12 Tuazon MA, Campbell SC, Klein DJ, Shapses SA, Anacker KR, Anthony TG, Uzumcu M \& Henderson GC. Effects of ovariectomy and exercise training intensity on energy substrate and hepatic lipid metabolism, and spontaneous physical activity in mice. Metabolism: Clinical and Experimental 201883 234-244. (https://doi. org/10.1016/j.metabol.2018.02.011)

13 Zhu L, Brown WC, Cai Q, Krust A, Chambon P, McGuinness OP \& Stafford JM. Estrogen treatment after ovariectomy protects against fatty liver and may improve pathway-selective insulin resistance. Diabetes 201362 424-434. (https://doi.org/10.2337/db11-1718)

14 Park SB, Lee YJ \& Chung CK. Bone mineral density changes after ovariectomy in rats as an osteopenic model: stepwise description of double dorso-lateral approach. Journal of Korean Neurosurgical Society 201048 309-312. (https://doi.org/10.3340/jkns.2010.48.4.309)

15 Struck MB, Andrutis KA, Ramirez HE \& Battles AH. Effect of a shortterm fast on ketamine-xylazine anesthesia in rats. Journal of the American Association for Laboratory Animal Science 201150 344-348.

16 Pantaleão TU, Mousovich F, Rosenthal D, Padrón AS, Carvalho DP $\&$ da Costa VMC. Effect of serum estradiol and leptin levels on thyroid function, food intake and body weight gain in female Wistar rats. Steroids 201075 638-642. (https://doi.org/10.1016/j. steroids.2010.03.009)

17 Castro BBA de, Colugnati FAB, Cenedeze MA, Suassuna PG de A \& Pinheiro HS. Standardization of renal function evaluation in Wistar rats (Rattus norvegicus) from the Federal University of Juiz de Fora's

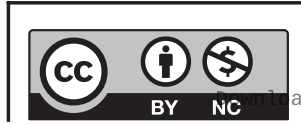

This work is licensed under a Creative Commons Attribution-NonCommercial 4.0 International License. ded from Bioscientifica.com at 04/26/2023 01:00:28PM 
colony. Journal Brasileiro de Nefrologia 201436 139-149. (https://doi.org/10.5935/0101-2800.20140023)

18 Dhar I, Dhar A, Wu L \& Desai KM. Increased methylglyoxal formation with upregulation of renin angiotensin system in fructose fed Sprague Dawley rats. PLOS ONE 20138 e74212. (https://doi. org/10.1371/journal.pone.0074212)

19 Ashour AE, Sayed-Ahmed MM, Abd-Allah AR, Korashy HM, Maayah ZH, Alkhalidi H, Mubarak M \& Alhaider A. Metformin rescues the myocardium from doxorubicin-induced energy starvation and mitochondrial damage in rats. Oxidative Medicine and Cellular Longevity 20122012 434195. (https://doi.org/10.1155/2012/434195)

20 Verma S \& McNeill JH. Metformin improves cardiac function in isolated streptozotocin-diabetic rat hearts. American Journal of Physiology 1994266 H714-H719. (https://doi.org/10.1152/ ajpheart.1994.266.2.H714)

21 Ndeingang EC, Defo Deeh PB, Watcho P \& Kamanyi A. Phyllanthus muellerianus (Euphorbiaceae) restores ovarian functions in letrozole-induced polycystic ovarian syndrome in rats. Evidence-Based Complementary and Alternative Medicine 20192019 1-16. (https://doi.org/10.1155/2019/2965821)

22 Lee HJ, Cantú SM, Donoso AS, Choi MR, Peredo HA \& Puyó AM. Metformin prevents vascular prostanoid release alterations induced by a high-fat diet in rats. Autonomic and Autacoid Pharmacology 2017 37 37-43. (https://doi.org/10.1111/aap.12057)

23 Rehman K, Saeed K, Munawar SM \& Akash MSH. Resveratrol regulates hyperglycemia-induced modulations in experimental diabetic animal model. Biomedicine and Pharmacotherapy 2018102 140-146. (https://doi.org/10.1016/j.biopha.2018.03.050)

24 Katz A, Nambi SS, Mather K, Baron AD, Follmann DA, Sullivan G \& Quon MJ. Quantitative insulin sensitivity check index: a simple, accurate method for assessing insulin sensitivity in humans. Journal of Clinical Endocrinology and Metabolism 200085 2402-2410. (https:// doi.org/10.1210/jcem.85.7.6661)

25 Bucolo G \& David H. Quantitative determination of serum triglycerides by the use of enzymes. Clinical Chemistry 197319 476-482.

26 Allain CC, Poon LS, Chan CS, Richmond W \& Fu PC. Enzymatic determination of total serum cholesterol. Clinical Chemistry 197420 470-475.

27 Nigro M, Santos AT, Barthem CS, Louzada RA, Fortunato RS, Ketzer LA, Carvalho DP \& de Meis L. A change in liver metabolism but not in brown adipose tissue thermogenesis is an early event in ovariectomy-induced obesity in rats. Endocrinology 2014155 2881-2891. (https://doi.org/10.1210/en.2013-1385)

28 Smith PK, Krohn RI, Hermanson GT, Mallia AK, Gartner FH, Provenzano MD, Fujimoto EK, Goeke NM, Olson BJ \& Klenk DC. Measurement of protein using bicinchoninic acid. Analytical Biochemistry 1985150 76-85. (https://doi.org/10.1016/00032697(85)90442-7)

29 Laemmli UK. Cleavage of structural proteins during the assembly of the head of bacteriophage T4. Nature 1970227 680-685. (https://doi. org/10.1038/227680a0)

30 Schneider CA, Rasband WS \& Eliceiri KW. NIH image to ImageJ: 25 years of image analysis. Nature Methods 20129 671-675. (https://doi. org/10.1038/nmeth.2089)

31 Fisher B, Gunduz N, Saffer EA \& Zheng S. Relation of estrogen and its receptor to rat liver growth and regeneration. Cancer Research 1984 44 2410-2415.

32 Herzig S \& Shaw RJ. AMPK: guardian of metabolism and mitochondrial homeostasis. Nature Reviews: Molecular Cell Biology 201819 121-135. (https://doi.org/10.1038/nrm.2017.95)

33 Salpeter SR, Buckley NS, Kahn JA \& Salpeter EE. Meta-analysis: metformin treatment in persons at risk for diabetes mellitus. American Journal of Medicine 2008121 149.e2-157.e2. (https://doi. org/10.1016/j.amjmed.2007.09.016)
34 Khan S \& Jena G. Sodium butyrate reduces insulin-resistance, fat accumulation and dyslipidemia in type- 2 diabetic rat: a comparative study with metformin. Chemico-Biological Interactions 2016254 124-134. (https://doi.org/10.1016/j.cbi.2016.06.007)

35 Kim EK, Lee SH, Jhun JY, Byun JK, Jeong JH, Lee SY, Kim JK, Choi JY $\&$ Cho ML. Metformin prevents fatty liver and improves balance of white/brown adipose in an obesity mouse model by inducing FGF21. Mediators of Inflammation 20162016 5813030. (https://doi. org/10.1155/2016/5813030)

36 Yan L, Kang B, Li G, Yin Z \& Wang Y. Effects of metformin on serum levels of sex hormone, leptin and insulin in ovariectomized SpragueDawley rats. Pharmazie 200964 834-835.

37 Sivasinprasasn S, Sa-nguanmoo P, Pongkan W, Pratchayasakul W, Chattipakorn SC \& Chattipakorn N. Estrogen and DPP4 inhibitor, but not metformin, exert cardioprotection via attenuating cardiac mitochondrial dysfunction in obese insulin-resistant and estrogendeprived female rats. Menopause 201623 894-902. (https://doi. org/10.1097/GME.0000000000000640)

38 Jeyabalan J, Viollet B, Smitham P, Ellis SA, Zaman G, Bardin C, Goodship A, Roux JP, Pierre M \& Chenu C. The anti-diabetic drug metformin does not affect bone mass in vivo or fracture healing. Osteoporosis International 201324 2659-2670. (https://doi. org/10.1007/s00198-013-2371-0)

39 Park YM, Rector RS, Thyfault JP, Zidon TM, Padilla J, Welly RJ, Meers GM, Morris ME, Britton SL, Koch LG, et al. Effects of ovariectomy and intrinsic aerobic capacity on tissue-specific insulin sensitivity. American Journal of Physiology: Endocrinology and Metabolism 2016310 E190-E199. (https://doi.org/10.1152/ ajpendo.00434.2015)

40 Banin RM, de Andrade IS, Cerutti SM, Oyama LM, Telles MM \& Ribeiro EB. Ginkgo biloba Extract (GbE) stimulates the hypothalamic serotonergic system and attenuates obesity in ovariectomized rats. Frontiers in Pharmacology 20178 605. (https://doi.org/10.3389/ fphar.2017.00605)

41 Stincic TL, Rønnekleiv OK \& Kelly MJ. Diverse actions of estradiol on anorexigenic and orexigenic hypothalamic arcuate neurons. Hormones and Behavior 2018104 146-155. (https://doi.org/10.1016/j. yhbeh.2018.04.001)

42 Chau-Van C, Gamba M, Salvi R, Gaillard RC \& Pralong FP. Metformin inhibits adenosine 5'-monophosphate-activated kinase activation and prevents increases in neuropeptide $\mathrm{Y}$ expression in cultured hypothalamic neurons. Endocrinology 2007148 507-511. (https:// doi.org/10.1210/en.2006-1237)

43 Lv WS, Wen JP, Li L, Sun RX, Wang J, Xian YX, Cao CX, Wang YL $\&$ Gao YY. The effect of metformin on food intake and its potential role in hypothalamic regulation in obese diabetic rats. Brain Research 20121444 11-19. (https://doi.org/10.1016/j.brainres.2012.01.028)

44 Santos RS, Batista TM, Camargo RL, Morato PN, Borck PC, Leite NC, Kurauti MA, Wanschel ACBA, Nadal Á, Clegg DJ, et al. Lacking of estradiol reduces insulin exocytosis from pancreatic $\beta$-cells and increases hepatic insulin degradation. Steroids 2016114 16-24. (https://doi.org/10.1016/j.steroids.2016.05.002)

45 Lu KH, Hopper BR, Vargo TM \& Yen SSC. Chronological changes in sex steroid, gonadotropin and prolactin secretion in aging female rats displaying different reproductive states. Biology of Reproduction 197921 193-203. (https://doi.org/10.1095/biolreprod21.1.193)

46 Ignacio DL, da S Silvestre DH, Cavalcanti-de-Albuquerque JP, Louzada RA, Carvalho DP \& Werneck-de-Castro JP. Thyroid hormone and estrogen regulate exercise-induced growth hormone release. PLOS ONE 201510 e0122556. (https://doi.org/10.1371/journal. pone.0122556)

47 Pedram A, Razandi M, O’Mahony F, Harvey H, Harvey BJ \& Levin ER. Estrogen reduces lipid content in the liver exclusively from membrane receptor signaling. Science Signaling 20136 ra36-ra36. (https://doi.org/10.1126/scisignal.2004013) https://ec.bioscientifica.com https://doi.org/10.1530/EC-19-0470 (c) 2019 The authors Published by Bioscientifica Ltd

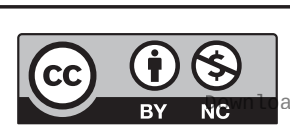

This work is licensed under a Creative Commons Attribution-NonCommercial 4.0 International License. ded from Bioscientifica.com at 04/26/2023 01:00:28PM 
48 Sutjarit N, Sueajai J, Boonmuen N, Sornkaew N, Suksamrarn A, Tuchinda P, Zhu W, Weerachayaphorn J \& Piyachaturawat P. Curcuma comosa reduces visceral adipose tissue and improves dyslipidemia in ovariectomized rats. Journal of Ethnopharmacology 2018215 167-175. (https://doi.org/10.1016/j.jep.2017.12.027)

49 Sharma Y, Bashir S, Ansarullah F, Faraz Khan M, Ahmad A \& Khan F. Inhibition of Src homology 2 domain containing protein tyrosine phosphatase as the possible mechanism of metformin-assisted amelioration of obesity induced insulin resistance in high fat diet fed C57BL/6J mice. Biochemical and Biophysical Research Communications 2017487 54-61. (https://doi.org/10.1016/j.bbrc.2017.04.012)

50 Gopoju R, Panangipalli S \& Kotamraju S. Metformin treatment prevents SREBP2-mediated cholesterol uptake and improves lipid homeostasis during oxidative stress-induced atherosclerosis. Free Radical Biology and Medicine 2018118 85-97. (https://doi. org/10.1016/j.freeradbiomed.2018.02.031)

51 Farahnak Z, Côté I, Ngo Sock ET \& Lavoie JM. High dietary cholesterol and ovariectomy in rats repress gene expression of key markers of VLDL and bile acid metabolism in liver. Lipids in Health and Disease 201514 125. (https://doi.org/10.1186/s12944-015-0128-9)

52 Ngo Sock E, Côté I, Mentor J, Prud'homme D, Bergeron R and Lavoie J-M. Ovariectomy stimulates hepatic fat and cholesterol accumulation in high-fat diet-fed rats. Hormone and Metabolic Research 201245 283-290. (https://doi.org/10.2337/db13-0194)

53 Geerling JJ, Boon MR, Van Der Zon GC, Van Den Berg SA, Van Den Hoek AM, Lombès M, Princen HMG, Havekes LM, Rensen PCN \& Guigas B. Metformin lowers plasma triglycerides by promoting vldltriglyceride clearance by brown adipose tissue in mice. Diabetes 2014 63 880-891. (https://doi.org/10.1055/s-0032-1329964)

54 Madiraju AK, Erion DM, Rahimi Y, Zhang XM, Braddock DT, Albright RA, Prigaro BJ, Wood JL, Bhanot S, MacDonald MJ, et al.
Metformin suppresses gluconeogenesis by inhibiting mitochondrial glycerophosphate dehydrogenase. Nature $2014510542-546$. (https://doi.org/10.1038/nature13270)

55 Zhou G, Myers R, Li Y, Chen Y, Shen X, Fenyk-Melody J, Wu M, Ventre J, Doebber T, Fujii N, et al. Role of AMP-activated protein kinase in mechanism of metformin action. Journal of Clinical Investigation $2001 \mathbf{1 0 8} 1167-1174$. (https://doi.org/10.1172/ JCI13505)

56 Camporez JPG, Jornayvaz FR, Lee HY, Kanda S, Guigni BA, Kahn M, Samuel VT, Carvalho CRO, Petersen KF, Jurczak MJ, et al. Cellular mechanism by which estradiol protects female ovariectomized mice from high-fat diet-induced hepatic and muscle insulin resistance. Endocrinology 2013154 1021-1028. (https://doi.org/10.1210/ en.2012-1989)

57 Capllonch-Amer G, Sbert-Roig M, Galmes-Pascual BM, Proenza AM, Llado I, Gianotti M \& Garcia-Palmer FJ. Estradiol stimulates mitochondrial biogenesis and adiponectin expression in skeletal muscle. Journal of Endocrinology 2014221 391-403. (https://doi. org/10.1530/JOE-14-0008)

58 Kim JY, Jo KJ, Kim OS, Kim BJ, Kang DW, Lee KH, Baik HW, Han MS \& Lee SK. Parenteral 17beta-estradiol decreases fasting blood glucose levels in non-obese mice with short-term ovariectomy. Life Sciences 201087 358-366. (https://doi.org/10.1016/j.lfs.2010.07.009)

59 Mauvais-Jarvis F, Clegg DJ \& Hevener AL. The role of estrogens in control of energy balance and glucose homeostasis. Endocrine Reviews 201334 309-338. (https://doi.org/10.1210/er.2012-1055)

60 Fullerton MD, Galic S, Marcinko K, Sikkema S, Pulinilkunnil T, Chen ZP, O’Neill HM, Ford RJ, Palanivel R, O’Brien M, et al. Single phosphorylation sites in Acc1 and Acc2 regulate lipid homeostasis and the insulin-sensitizing effects of metformin. Nature Medicine 201319 1649-1654. (https://doi.org/10.1038/nm.3372)

Received in final form 24 October 2019

Accepted 19 November 2019

Accepted Preprint published online 20 November 2019
This work is licensed under a Creative Commons Attribution-NonCommercial 4.0 International License. ded from Bioscientifica.com at 04/26/2023 01:00:28PM 